\title{
The sportivization process of a martial art: the karate
}

\author{
Marcelo Alberto de OLIVEIRA*1, Jefferson Campos LOPES ${ }^{2}$, Ricardo João SONODA-NUNES 3 , \\ Abel FIGUEIREDO 4 \\ ${ }^{1}$ University of São Paulo (Brazil) \\ ${ }^{2}$ São Vicente College of Technology (Brazil) \\ ${ }^{3}$ Federal University of Paraná (Brazil) \\ ${ }^{3}$ Polytechnic Institute of Viseu (Portugal)
}

8th IMACSSS International Conference Abstracts, Viseu (Portugal), October 10-12, 2019

Type: Oral communication

\begin{abstract}
This study addresses the historical trajectory of karate, particularly in relation to the processes that favored its inclusion as one of the five modalities that will debut at the 2020 Olympic Games in Tokyo, Japan. The literature review was the methodology used in this research. Several attempts and efforts were identified to enable karate to join as a sport in the Olympic Games. It was concluded that the agents (federation leaders, presidents, coaches and athletes) along with institutions (clubs, companies, government, among others) were involved in a process that aimed to meet the requirements of the International Olympic Committee. Thus, it is possible to observe various transformations in the development of this modality that shaped karate as it is today, which has made it a rookie modality being conditioned by market interests.
\end{abstract}

Keywords: Martial arts; combat sports; Karate; Olympic Games; Olympic movement; sportivization process.

\section{Introduction}

This study addresses the historical trajectory of karate, particularly regarding processes that favored its inclusion (several structural transformations) as one of the five modalities that will debut at the 2020 Olympics in Tokyo, Japan (climbing, surfing, skateboarding, karate and baseball/softball). There have been several transformations in karate. In this context, we can mention the implementation of sporting characteristics for karate (during the 1950s), following the arousal of the first Karate Championships and culminating with the implementation of accessories and safety materials to preserve the physical integrity of athletes (Frosi \& Mazo, 2011; Guttmann \& Thompson, 2001; Pucineli, 2017). Thus, one of the main aims of this work was to understand the sportivization process of karate. Also in this context, identifying the existing ruptures in its transformations. Finally, this work narrates theoretical references from the history and sociology of sport the behavior of the sports field of karate.

\section{Methodology}

The literature review was the methodology used in this research. In this context, from scientific articles, master's dissertations, doctoral theses and various books we were able to map the state of the art. Frosi \& Mazo (2011), Guttmann \& Thompson, 2001, Pucineli (2017), Barreira (2013) and Oliveira et al (2019) provide relevant information on the historical transformations of karate during the twentieth century.

\section{Results and Discussion}

There have been various attempts and efforts by different agents and organizations worldwide and nationally to direct karate at the Olympic Games. The participation of federation presidents and world organizations was fundamental for karate to fit to the Olympic modalities

\footnotetext{
*Email: marcelo.alberto@usp.br
} 
framework. Agents (federation leaders, presidents, coaches and athletes), along with institutions (clubs, companies, government, among others) were involved in a process aimed at meeting the requirements of the International Olympic Committee (Barreira, 2013; Oliveira, Telles \& Barrier, 2019). In this context, there was a constant movement of changes, towards the accomplishment of a sportivization process that includes: changes of rules and norms, aiming at preserving the physical integrity of the athletes. The rules also provided greater movement among athletes, allowing more time to fight and performing more strikes (JKA, 2018). We also observed the replacement of equipment and the inclusion of safety accessories for athletes (implantation of gloves, shin guards, protection for men's genitals, pectoral protection for women, mouth guard, rubberized floor, tatami, among others); adhesion of technological tools (electronic scoreboard to score points and video review to answer questions during fights).

\section{Conclusion}

Thus, it is possible to observe various transformations in the development of this modality that shaped what karate is today, which has made it a modern sports modality conditioned by the interests of the market.

\section{References}

Barreira, C. R. A. (2013). O sentido do Karate-Do: faces históricas, psicologicas e fenomenológicas (1st ed.). Rio de Janeiro, Rio de Janeiro: E-papers.

Frosi, T. O., \& Mazo, J. Z. (2011). Repensando a história do karate contada no Brasil. Revista Brasileira de Educação Física e Esporte, 25(2), 297-312. doi: 10.1590/S1807$\underline{55092011000200011}$

Guttmann, A., \& Thompson, L. (2001). Japanese sports: a history. Hawai'i: University of Hawai'i Press.

JKA. (2018). History of JKA. Retrieved from https://www.jka.or.jp/en/about-jka/history

Oliveira, M. A. de, Telles, T. C. B., \& Barreira, C. R. A. (2019). De Okinawa aos Jogos Olímpicos: o Karate. In Do pós ao Neo Olimpismo: esporte e movimento olímpico no século XXI (pp. 327347). São Paulo: Képos.

Pucineli, F. A. (2017). Modernização do Karate: Gichin Funakoshi e as Tecnologias Políticas do Corpo. Universidade Estadual Paulista, UNESP. 